\title{
ママカリ酢漬製品の乳酸菌による膨化現象
}

\author{
河野勇人 \\ (岡山県工業技術センター) \\ （受付：平成 18 年 10 月 23 日） \\ （受理：平成 19 年 1 月 30 日）
}

\section{Swelling of Packaged Mamakari Fish in Vinegar by Lactic Acid Bacteria}

\author{
Isato KonO \\ (Industrial Technology Center of Okayama Prefecture, Haga 5301, \\ Okayama-shi, Okayama 701-1296)
}

\begin{abstract}
The swelling phenomenon of packages containing Mamakari fish treated with vinegar seasoning was observed. Analysis of the swollen sample revealed lactic acid bacteria but not in a normal sample, and the isolate was identified as Lactobacillus brevis. The process of carbon dioxide gas production was supposed by heterofermentation and glutamate decarboxylation. Growth of the isolate was inhibited additively in a mixed solution containing acetic acid, lactic acid and $\mathrm{NaCl}$. Accordingly, it is shown that growth of the isolate causing swelling of the package was inhibited by vinegar seasoning containing appropriate organic acid contents.
\end{abstract}

Key words: Lactobacillus brevis, Swelling, Organic acid

緒言

ママカリ酢漬製品は，ニシン科のママカリを調味酢に 漬け込んだ食品で，岡山県をはじめとする瀬戸内地方の 代表的な特産品である. 本品は加熱殺菌処理をせず, 調 味酢に漬けた状態で密封包装し, 製品化される。本品は 常温流通にした場合，特に夏期の温度が高い時季におい て，製品の袋が膨張する“膨れ”の問題がしばしば生じ る.

加工食品の品質劣化, 特に加熱殺菌処理できない包装 食品の膨化現象は, 微生物に起因することが多い. ママ カリ䣷漬包装食品の膨れ原因についても, 製品中に生育 する酵母 (Debaryomyces hansenii) の再発酵によること が，これまでに報告されている1).

ここでは, 膨張し返品された県内メーカー製のママカ リ酢漬製品についてその原因を検討した結果，従来の酵 母菌による膨化とは違い, 乳酸菌がその原因菌と認めら れたこと, ならびにその膨化防止対策について検討した 結果について報告する.

馬701-1296 岡山市芳賀 5301
方法

\section{1. 使用材料}

供試試料は，頭部と内蔵を除いたママカリを塩漬け水 洗後, 調味䣷（砂糖 $25 \%$, グルタミン酸ナトリウム $0.15 \%$, 食塩 $4 \%$, 酢酸 $1.1 \%$ ）に漬け込み，椎茸，生姜 を加えて密封包装したものを用いた．

\section{2. 微生物の培養}

乳酸菌の培養は, $\mathrm{MRS}$ 培地 (Difco) を用い, $30^{\circ} \mathrm{C}$ で 7 日間嫌気培養した。一般生菌数の測定は, 標準寒天培地 （ニッスイ）を用いて $37^{\circ} \mathrm{C}, 2$ 日間の平板培養法により, また真菌数の測定は Potato Dextrose Agar 培地 (Difco) を用いて $30^{\circ} \mathrm{C}, 5$ 日間の平板培養法により行った。調味 酢ならびに試料浸漬液は膜ろ過 $(\phi 0.20 \mu \mathrm{m})$ し, 前培養 した微生物を $10^{5}$ cells $/ \mathrm{m} l$ 植菌後, $30^{\circ} \mathrm{C}, 7$ 日間静置培 養した。菌の生育は, 吸光度 $\left(\mathrm{OD}_{660}\right)$ の測定によった。細 菌の同定は, 細菌同定検査用キットApi $50 \mathrm{CH}$ (bioMerieux) での培養結果ならびに Bergey's Manual of Systematic Bacteriology ${ }^{2)}$ に準拠して行った.

\section{3. 成分分析}

乳酸の分析は，F-キットD-乳酸/L-乳酸 (Roche Diag- 
nostics) を用いて測定した。有機酸の分析は，有機酸分 析システム（島津 HPLC Organic Acid Analysis System）を用いて，アミノ酸はアミノ酸分析計（日立高速 アミノ酸分析計 835 形) により, 糖の分析は糖分析シス テム（島津）を用いて，エタノールはガスクロマトグラ フ $(\mathrm{DBWAX}$, キャピラリーカラム) により, 塩分は電位 差自動滴定装置（京都電子工業 AT-200）を用いて定量 した，供試試料中の二酸化炭素は，二酸化炭素検知管 （ガステック）を用いて測定した.

\section{結果および考察}

\section{1. 膨化製品の分析}

膨化製品中のガスを分析した結果，主成分は二酸化炭 素であった. 膨化製品と正常品の浸漬調味酢液の成分分 析の結果を Table 1 に示した。これより, 膨化製品の特 徵として, $\mathrm{pH}$ と糖 (ショ糖) が減少し, 乳酸とエ夕ノ一

Table 1. Analysis of vinegar seasoning contents of treated Mamakari fish

\begin{tabular}{|c|c|c|}
\hline & $\begin{array}{l}\text { Normal } \\
\text { sample }\end{array}$ & $\begin{array}{l}\text { Swelled } \\
\text { sample }\end{array}$ \\
\hline $\mathrm{pH}$ & 4.3 & 4.0 \\
\hline \multicolumn{3}{|l|}{ Sugars (\%) } \\
\hline Sucrose & 11.6 & 6.5 \\
\hline Glucose & 0.5 & 0.4 \\
\hline Fructose & 0.2 & 0.4 \\
\hline Ethanol (\%) & 0.2 & 0.8 \\
\hline $\mathrm{NaCl}(\%)$ & 3.5 & 3.5 \\
\hline \multicolumn{3}{|l|}{ Organic acid $(\mathrm{mmol} / l)$} \\
\hline Citric acid & 2.6 & 2.8 \\
\hline Gluconic acid & 7.7 & ND* \\
\hline Malic acid & 1.8 & 0.5 \\
\hline Succinic acid & 1.1 & 1.1 \\
\hline Lactic acid & 16.8 & 131.3 \\
\hline Formic acid & 0.7 & 1.3 \\
\hline Acetic acid & 145.4 & 212.8 \\
\hline Pyroglutamic acid & 1.0 & 1.8 \\
\hline \multicolumn{3}{|l|}{ Amino acid $(\mathrm{mmol} / l)$} \\
\hline Asp & 8.9 & 12.1 \\
\hline Thr & 7.7 & 10.5 \\
\hline Ser & 5.6 & 10.2 \\
\hline Glu & 17.7 & 2.5 \\
\hline Gly & 5.3 & 13.3 \\
\hline Ala & 12.6 & 21.7 \\
\hline Val & 12.2 & 14.7 \\
\hline Met & 5.8 & 11.2 \\
\hline Ileu & 8.5 & 11.3 \\
\hline Leu & 17.1 & 25.5 \\
\hline Tyr & 2.5 & 1.0 \\
\hline Phe & 15.5 & 15.5 \\
\hline GABA & 1.2 & 21.2 \\
\hline Lys & 13.3 & 18.3 \\
\hline $\mathrm{NH}_{3}$ & 18.8 & 39.7 \\
\hline His & 6.6 & 7.6 \\
\hline Arg & 5.3 & 3.0 \\
\hline Living cells (cells/ml) & $9.0 \times 10^{2}$ & $2.9 \times 10^{9}$ \\
\hline Yeasts $($ cells $/ \mathrm{m} l)$ & $3.3 \times 10^{2}$ & ND \\
\hline Lactic acid bacteria (cells $/ \mathrm{m} l$ ) & $3.0 \times 10^{2}$ & $2.7 \times 10^{9}$ \\
\hline
\end{tabular}

* Not detected.
ルがほぼ等モル生成し，また䣷酸やギ酸も生成したのに 対し，グルコン酸は膨化製品では検出されなかった。ア ミノ酸については, グルタミン酸が減少し, 逆にほぼ等 モルの $\gamma$-アミノ酪酸が生成した。浸漬調味䣷液中の菌数 を測定した結果，正常品ではほとんど生菌は検出されな かった。それに対し膨化製品では，標準寒天培地で検出 された生菌数が $2.9 \times 10^{9} \mathrm{cells} / \mathrm{m} l$, また MRS 培地で検 出した菌数は $2.8 \times 10^{9} \mathrm{cells} / \mathrm{m} l$ であり，コロニーの性 状む同一で，そのほとんどが乳酸菌と考えられた。なお， 酵母は検出されなかった。

\section{2. 分離株の同定}

MRS 培地のコロニーからランダムに 10 株を釣菌し 分離株とした。これらの分離株を，水で 2 倍希釈した調 味䣷で $30^{\circ} \mathrm{C}, 7$ 日間静置培養した結果, いずれも二酸化 炭素の生成を確認した。これらの菌の性状を検討した結 果を Table 2 に示した. 分離した 10 株はいずれむ同じ 結果であった。 これらの菌の性状ならびに細菌同定検査 用キットの結果 (\%ID; 99.9, T index; 0.40) より, 分離菌 は Lactobacillus brevis と推定された. L. brevis は, ミ ルク, チーズ, 漬物, またニシンの酢漬けなどから分離

Table 2. Physiological characteristics of isolate

\begin{tabular}{|c|c|c|}
\hline & Isolate & L. brevis ${ }^{2)}$ \\
\hline Shape & rod & rod \\
\hline Gram stain & + & + \\
\hline Catalase & - & - \\
\hline Spore formation & - & - \\
\hline Anaerobic culture & + & + \\
\hline Growth in MRS medium & + & + \\
\hline \multicolumn{3}{|l|}{ Temperature requirement } \\
\hline $45^{\circ} \mathrm{C}$ & - & - \\
\hline $15^{\circ} \mathrm{C}$ & + & + \\
\hline Optical form of lactic acid & $\mathrm{DL}$ & DL \\
\hline \multicolumn{3}{|l|}{ Fermentation } \\
\hline glucose & + & + \\
\hline fructose & + & + \\
\hline mannose & - & - \\
\hline arabinose & + & + \\
\hline ribose & + & + \\
\hline xylose & + & $\mathrm{d}$ \\
\hline rhamnose & - & - \\
\hline mannitol & - & - \\
\hline sorbitol & - & - \\
\hline galactose & + & $\mathrm{d}$ \\
\hline sucrose & + & $\mathrm{d}$ \\
\hline trehalose & - & - \\
\hline amygdalin & - & - \\
\hline melezitose & + & - \\
\hline raffinose & + & $\mathrm{d}$ \\
\hline esculin & \pm & $\mathrm{d}$ \\
\hline salicin & - & - \\
\hline cellobiose & - & - \\
\hline maltose & + & + \\
\hline lactose & + & $\mathrm{d}$ \\
\hline melibiose & + & + \\
\hline gluconate & + & + \\
\hline
\end{tabular}

$+; 90 \%$ or more strains positive, - ; $90 \%$ or more strains negative, d; $11-89 \%$ strains positive. 
される耐塩性・酢酸耐性の乳酸菌であり，生育限界食塩 (\%) は 6.5, 生育 $\mathrm{pH}$ 域は 3.7〜 4.2 であると報告2),3) され ており，膨化製品の浸漬調味酢液で L. brevis が生育で きることを裏づけている. なお分離株の由来を検討する ため, ママカリ䣷漬製品材料（魚体，調味酢，椎茸，生 姜）から乳酸菌を分離した結果, 魚体のみから乳酸菌が 検出されたことから, 分離株は魚体由来と推定された。

\section{3. 分離株の発酵形式}

乳酸菌による二酸化炭素の生成は, ヘテロ型発酵によ る生成, アミノ酸の脱炭酸反応, またマロラクティック 発酵による生成などが知られている，本ママカリ酢漬製 品は, 調味酢にグルタミン酸ナトリウムを $0.15 \%$ 添加 しており, 他のアミノ酸に比べて, 特にその含量が多い. 微生物には各種アミノ酸脱炭酸酵素が広く存在し, 本分 離株の L. brevis は, グルタミン酸をはじめとするアミ ノ酸を脱炭酸することが知られている4 6).

そこで，分離株の発酵形式を検討するため， MRS 培 地を基本培地とし，これにグルタミン酸 $68 \mathrm{mM}$ を添加 した培地に分離株を植菌し, $30^{\circ} \mathrm{C}$ で 6 日間静置培養し た。培養液の成分分析結果を Table 3 に示した. MRS 培地で培養した場合, 乳酸, エ夕ノール, $\mathrm{CO}_{2}$ がおよそ 等モル生成した。またこれらの生成比より, 本分離株は ヘテロ型発酵の形式をとると思われた7)。 また MRS に グルタミン酸を添加した場合, 発生する二酸化炭素量 は, 添加したグルタミン酸のモル数に比例して増加し た. 乳酸菌は, クエン酸回路の 2 -オキソグルタル酸合成 が遮断されているためグルタミン酸生合成機能が欠如 ${ }^{8)}$ しており, 生育にグルタミン酸を必要とする。この分離 したL. brevis では，グルタミン酸量は添加した量がほ ぼ消費され, 逆に $\gamma$-アミノ酪酸が増加した。したがって, ヘテロ型発酵とともに，グルタミン酸の脱炭酸反応を確 認した. なお, L. brevis はアルギニンの加水分解による アンモニアの生成反応屯知られている ${ }^{9)}$ が，これらの変 化量からこの分離株での反応は生じていないと思われ

Table 3. Analysis of fermented medium contents of isolate

\begin{tabular}{lccc}
\hline & MRS & MRS $+\mathrm{Glu}^{\mathrm{a}}$ & $\mathrm{MRS}+\mathrm{Glu}^{\mathrm{a}}+\mathrm{Asp}^{\mathrm{b}}$ \\
\hline $\mathrm{CO}_{2}$ & 79.4 & 134.7 & 138.3 \\
Lactic acid & 72.0 & 105.0 & 91.9 \\
Acetic acid & 58.0 & 41.0 & 48.0 \\
Ethanol & 62.4 & 53.0 & 45.1 \\
Asp & 0.2 & 0.7 & 86.0 \\
$\mathrm{Ala}$ & 4.0 & 3.0 & 3.0 \\
$\mathrm{Glu}$ & 0.6 & 0.6 & 1.0 \\
$\mathrm{GABA}$ & 3.0 & 71.0 & 71.0 \\
$\mathrm{Arg}$ & 0.3 & 0.4 & 0.2 \\
$\mathrm{NH}_{3}$ & 25.0 & 25.0 & 24.0 \\
\hline
\end{tabular}

$(\mathrm{mmol} / \mathrm{l})$

Glutamic acid ${ }^{\mathrm{a}}(68.0 \mathrm{mM})$ and aspartic acid ${ }^{\mathrm{b}}(75.0 \mathrm{mM})$ were added to MRS broth (Difco) and the isolate was cultured in this broth at $30^{\circ} \mathrm{C}$ for 5 days. After cultivation, these media were analyzed.
た.

ヘテロ型発酵による二酸化炭素の生成の場合，本分離 株の L. brevis はへテロ発酵型乳酸菌であることから， 糖とグルコン酸から二酸化炭素が生成する．グルコース の代謝については，Hexose monophosphate 経路によ り代謝されて二酸化炭素が生成する. Table 1 の生成モ ル数より発生する二酸化炭素は, 糖の発酵加調味液量 の約 2.6 倍量, グルコン酸発酵から調味液量の約 $22 \%$ 量の体積である。 またアミノ酸脱炭酸反応 ${ }^{4 \sim 6)}$ のうち, ヒスチジン5), チロシン ${ }^{6)}$ な゙のアミノ酸脱炭酸反応で は，発生する二酸化炭素の体積は調味液量の $10 \%$ 以下 であるのに対し，グルタミン酸ナトリウムが $0.15 \%$ 添 加された本製品の場合，グルタミン酸からの脱炭酸反応 により調味液量の約 34\% 量の二酸化炭素が生成してい る。またマロラクティック発酵10) で発生する二酸化炭素 量は，リンゴ酸含量から換算すると，調味液量の約 $4 \%$ にすぎない.

以上のことから，本膨化製品における二酸化炭素の発 生源は，乳酸菌による糖やグルコン酸を発酵するへテロ 型発酵とグルタミン酸の脱炭酸によると考えられる。こ れより，本ママカリ酢漬製品の膨化を抑制するために は，魚体中の L. brevis の生育を抑えることが必要であ る.

\section{4. 食品成分による静菌}

食品保存料を使わない膨化対策として，調味酢成分に よる静菌について検討した。本製品の調味酢の成分に は，有機酸，食塩などが含まれている，有機酸による静 菌効果については報告があり ${ }^{11)}$ ，そのうち酢酸と乳酸が 一般的に利用されている。特に乳酸については，酸の閾 值が低く $\mathrm{pH}$ を下げるが酸味を感じないこと，また乳酸 の解離定数 (3.86) は䣷酸 (4.76) より屯低いことから，利 用範囲が広い。また食塩についても，微生物の生育を阻 止する素材として広く利用されている．有機酸による分 離菌の静菌作用について，酢酸（Fig. 1) および乳酸 (Fig. 2) を検討した。 その結果，酢酸は $1 \%$ で，乳酸む 1\%で誘導期の遅延が認められた。また䣷酸と乳酸を併 用した場合，酢酸 $1 \%$ に乳酸 $0.2 \%$ を混合すると，分離

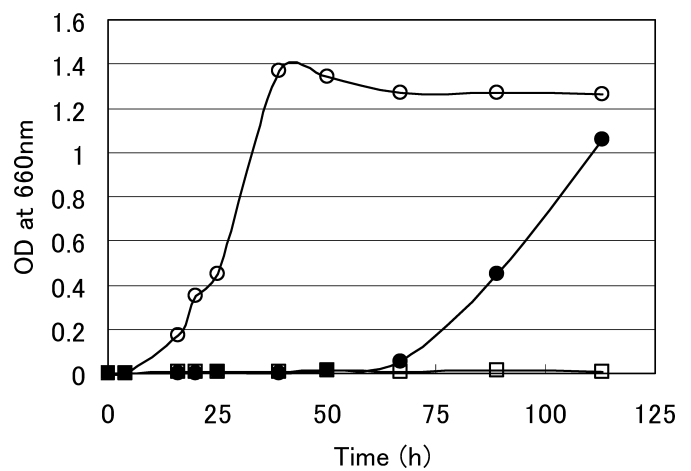

Fig. 1. Growth curve of isolate in broth containing acetic acid Acetic acid conc., $\bigcirc ; 0 \%, \bigcirc ; 1 \%, \square ; 2 \%$ 


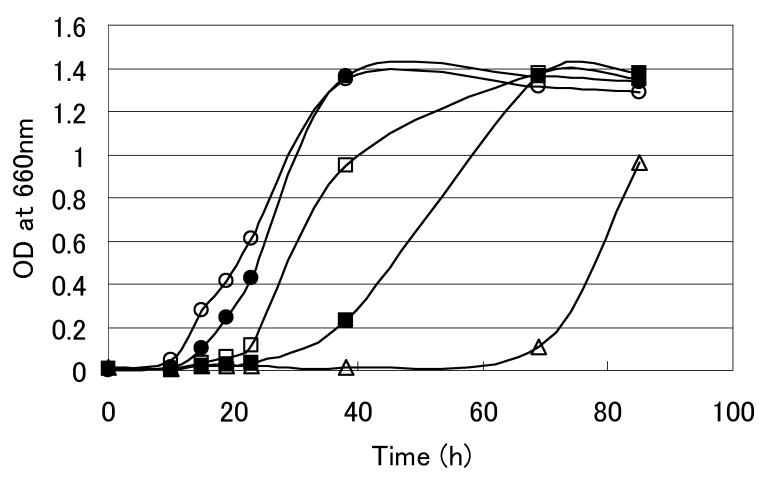

Fig. 2. Growth curve of isolate in broth containing lactic acid.

Lactic acid conc., $\bigcirc$; $0 \%, \bigcirc ; 0.4 \%, \square ; 0.6 \%$, ㅁ $0.8 \%, \triangle ; 1.0 \%$

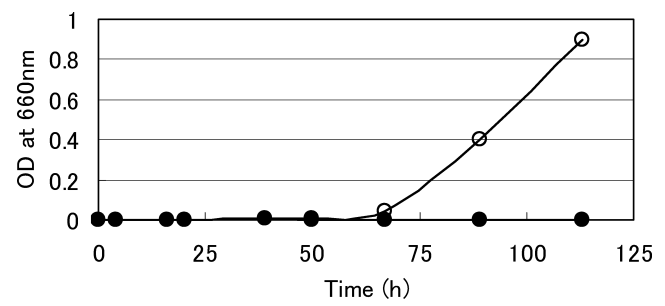

Fig. 3. Growth curve of isolate in broth containing lactic acid and 1\% acetic acid.

Lactic acid conc., $\bigcirc ; 0 \%, 0 ; 0.2 \%$

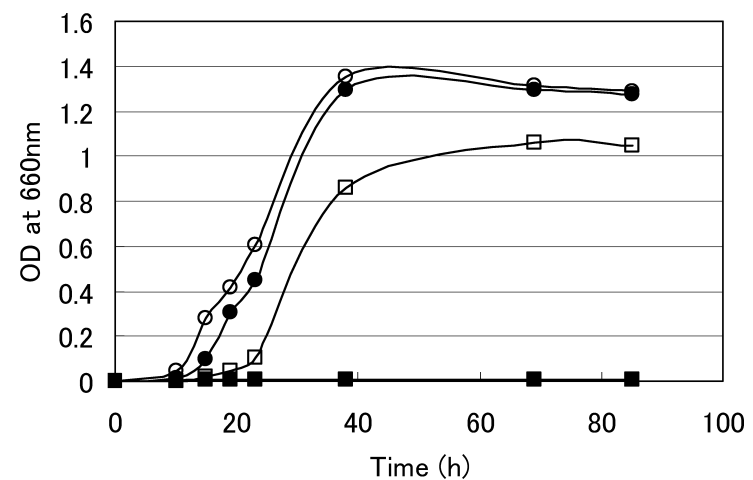

Fig. 4. Growth curve of isolate in broth containing $\mathrm{NaCl}$.

$\mathrm{NaCl}$ conc., $\bigcirc ; 0 \%, \bigcirc ; 2 \%, \square ; 4 \%, \square ; 6 \%$

株は生育せず，併用効果が認められた (Fig. 3). また, 食塩による静菌効果について検討した結果, 食塩濃度 6\% で生育が認められなかった (Fig. 4). 食塩と乳酸を 併用した場合，食塩 $4 \%$ に乳酸 $0.8 \%$ を混合すると分離 株の生育が認められず，相加的な抗菌作用が示された (Fig. 5). 本菌は, 正常品の浸漬液ならびに調味酢には生 育しなかった。これは以上の結果を裏づけるものであ る.

加工食品の膨化現象のうち，ママカリ酢漬製品と同様 に乳酸菌が原因菌であった例として, 減塩奨油 ${ }^{12)}$ や加工 味噌 ${ }^{13)}$ ，また小袋詰ストレートつゆ ${ }^{14)}$ などが報告されて いる. 特に, 本分離菌であるL. brevis は, 耐塩性・酢酸 而性の乳酸菌であり, ママカリ酢漬の調味液や正常品の

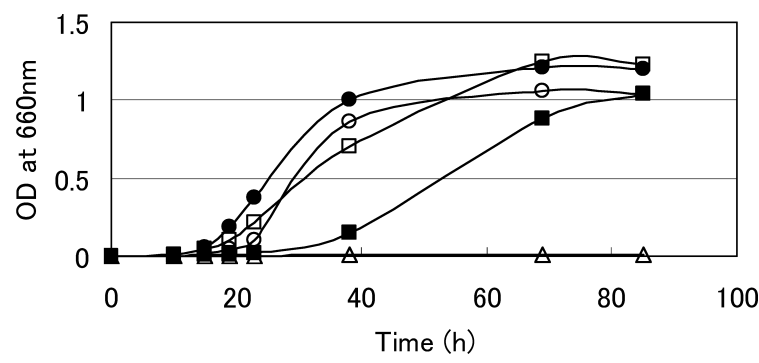

Fig. 5. Growth curve of isolate in broth containing lactic acid and $4 \% \mathrm{NaCl}$.

Lactic acid conc., $\bigcirc ; 0 \%, \mathbf{O} ; 0.2 \%, \square ; 0.4 \%$,

口; $0.6 \%, \triangle ; 0.8 \%$

浸漬液には本菌は生育しないが, 水での 2 倍希釈液では 生育が可能であった (デー夕未提示)，膨化製品と正常品 の浸漬液を比較 (Table 1) すると，膨化製品における工 夕ノールや乳酸の増加分に比べ酢酸の増加分が低い。 ま たママカリ酢漬において, 調味酢に魚体を加えると, 魚 体量に比例して調味䣷の $\mathrm{pH}$ は上昇する ${ }^{1)}$.これより, 浸 漬液の䣷酸をはじめとする有機酸濃度が魚体などの製品 材料により希釈され，また浸漬液の $\mathrm{pH}$ が上昇すること により, 本菌が生育したものと推測される。したがって, 製品中の有機酸（特に酢酸，乳酸）をはじめとする食品 成分の濃度を希釈を考慮に入れて適正に調整すること や，調味酢の $\mathrm{pH}$ 上昇を防ぐことにより，本製品の膨化 現象を抑制することが可能と考えられる.

\section{文献}

1) 合屋晏秀, 花井玲子, 斎藤昌義, 中村宗一郎: ママカリ酢 漬包装品のガス発生による膨張の防止対策. 日食工誌, 46, 170-176 (1999).

2) Kandler, O. and Weiss, N.: Bergey's Manual of Systematic Bacteriology Vol.2, p. 1208, Williams and Wilkins Co., Baltimore, USA (1986).

3) 好井久雄, 金子安之, 山口和夫：食品微生物学ハンド ブック，p. 227, 技報堂, 東京 (1995).

4) Park, K. B. and Oh, S. H.: Cloning, sequencing and expression of a novel glutamate decarboxylase gene from a newly isolated lactic acid bacterium, Lactobacillus brevis OPK-3. Bioresour. Technol., 98, 312-319 (2007).

5) Landete, J. M., Pardo, I. and Ferrer, S.: Histamine, histidine, and growth-phase mediated regulation of the histidine decarboxylase gene in lactic acid bacteria isolated from wine. FEMS Microbiol Lett., 260, 84-90 (2006).

6) Moreno-Arribas, V. and Lonvaud-Funel, A.: Tyrosine decarboxylase activity of Lactobacillus brevis IOEB 9809 isolated from wine and L. brevis ATCC 367. FEMS Microbiol Lett., 180, 55-60 (1999).

7) 内村 泰, 岡田早苗: 乳酸菌実験マニュアル. 小崎道雄 監修, p. 62, 朝倉書店, 東京 (1992).

8) 乳酸菌研究集談会: 乳酸菌の科学々技術, p. 126, 学会出 版センター, 東京 (2000). 
9) Liu, S.-Q., Holland, R. and Crow, V. L.: The potential of dairy lactic acid bacteria to metabolise amino acids via non-transaminating reactions and endogenous transamination. Int. J. Food Microbiol., 86, 257-269 (2003).

10) du Plessis, H. W., Dicks, L. M., Pretorius, I. S., Lambrechts, M. G. and du Toit, M.: Identification of lactic acid bacteria isolated from South African brandy base wines. Int. J. Food Microbiol., 91, 19-29 (2004).

11）松田敏生：食品微生物制御の化学, p. 116, 幸書房, 東京
(1998).

12）浦 哲二, 稲森和夫, 古屋 武, 内田一生：低塩奨油に生 育する微生物に関する研究（第 1 報）乳酸桿菌によるア ミノ酸の脱炭酸. 奨研, 14, 187-192 (1988).

13）新国佐幸, 石山朋治, 鈴木于七, 鈴木忠直, 小坂直治, 森 勝美：へテロ乳酸菌 Lactobacillus fructivorans に起因 する加工味増の膨れ。日食工誌，43, 910-916 (1996).

14）内藤茂三：包装食品の微生物変敗防止に関する研究（第 34 報）包装ストレートつゆの乳酸菌による膨張現象に ついて。愛知食品工技セ年報, 37, 39-47 (1996). 